\title{
TECHNOLOGICAL RESOURCES FOR LIFELONG LEARNING OF TEACHERS IN THE DIGITAL ERA: AN ANALYSIS FROM THE LEARNING ECOLOGIES
}

\author{
Alba Souto-Seijo, Iris Estévez, Mercedes González-Sanmamed, Patricia Romero, \\ Universidade da Coruña, Spain
}

\section{Introduction}

Permanent education has become not only a requirement, but an unavoidable necessity to respond to the requirements of the school, as a precise change for the quality of teaching and teacher training (Imbernón, 2014). The need for a permanent education is driven and/or promoted by the changes that society is generating, simultaneously, in the training and education processes, since the incorporation of ICT in these processes has caused a change in the relationship between the didactic components. Therefore, pedagogical practice must adopt new forms of work that adapt to the new training needs. Consequently, it can be said that education does not remain external to changes and incorporates new media in its didactic relationship, which causes a redefinition of the teacher's work and, surely of the teaching profession, of its formation and its development professional (Sangrà \& González Sanmamed, 2011).

Assuming the relationship of ICT with training implies admitting some changes in the structures in which such training converges. Thus, for example, educational institutions seek new strategies that facilitate change in the digital era and provide dynamic, creative responses that are commensurate with social demands (Carril, Sanmamed, \& Sellés, 2013).In line with previous ideas, the ecological metaphor or, properly, the Learning Ecologies provide an ideal analysis framework for the study of new forms of learning and professional development (Sangrà, González Sanmamed, \& Guitert, 2013; González-Sanmamed, Sangrá, Souto-Seijo, \& Estévez, 2018). In the words of Siemens (2010; p.63) the Learning Ecologies are "the space in which learning takes place". This author states that ecologies allow adaptation to the needs of agents within a space, so we can say that they are adaptive, dynamic and sensitive. For his part Barron (2006) considers ecology as "a series of contexts, found in physical or virtual spaces, that provide opportunities for learning. Each context is composed of unique activities, resources, relationships and interactions that arise in them" (Barron, 2006; p.195).

The ability to create and use a Learning Ecology to achieve a certain goal, implies a complex set of skills, qualities, elements and attitudes that must refer to the key dimensions of a learning ecology (Eraut, 2009). Within these key elements we can distinguish: activities, motivations, relationships, contexts, processes, and, also, resources. In this study we will focus 
on the analysis of this last key element of learning ecologies: resources. Understanding these, like those tools, with or without a technological base, that help teachers to develop professionally and stay updated.

For everything previously mentioned, the main purpose of this research is to understand and reflect on how Primary Education teachers carry out their training and professional development, and what is the role of resources (personal and technological) in the configuration of their Learning Ecologies.

\section{Methodology}

This research is of a qualitative nature. In addition, we must take into account, that it is launched within a biographical-narrative approach. The tradition of qualitative research relating to narrative is a form of qualitative research that deals with the analysis of human experience, more specifically "it studies the lives of people and asks one or more people to provide stories about their lives. It is then told by the researcher in a narrative chronology" (Clandinin \& Connelly, 2000). Other authors such as Creswell (2013) also define it as a research tradition in which narrative is understood as a spoken or written text that explains an event, an action or a series of events and/or actions, connected in chronological order.

\section{Participants}

The sample of our study is composed of 5 Primary Education teachers from different public schools in the province of A Coruña (Spain). To preserve the anonymity of the participants and the confidentiality of the data, we have assigned them different names instead of the real ones. The characteristics of our sample are presented in Figure 1.
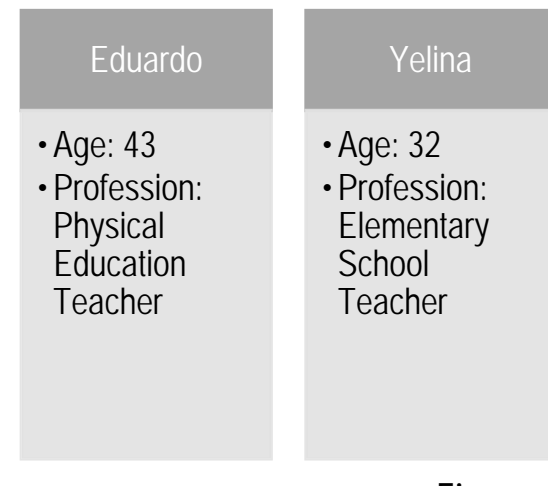

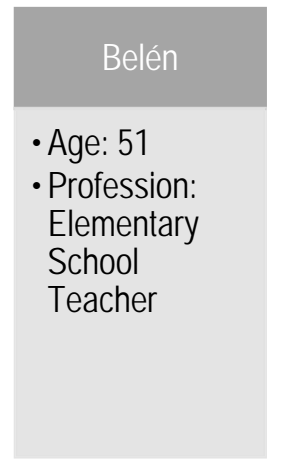

Figure 1. Participant Characteristics

\section{Instruments}

The data collection of the study has been carried out through an open-ended interview about learning mechanisms. This was made up of 71 questions, of which 25 related to learning resources used by teachers. Some of the questions that have allowed us to understand the meaning attributed to both technological and personal resources were, for instance, the following: 
"How does the update of your colleagues influence your own update?";

"What is your motivation to train yourself using ICT?";

"What technological tools do you use in your professional field?";

"What role do virtual platforms play in your training process?" and

"The aim was to identify the learning ecologies of each of the participants".

\section{Process}

First, we contacted with the selected teachers, to invite them to participate in the research, always ensuring confidentiality and anonymity. They were also informed of the importance of the study and its purpose. After that, their doubts were resolved, and the days were set with each of them to carry out the scheduled interview. In order to accurately record the interaction between the interviewer and the interviewee, a tape recorder was used. Then they were transcribed.

\section{Data analysis}

As determined by Glaser and Strauss $(1967 ; 1999)$ and Corbin and Strauss (2014), the interpretation of data is the essence of qualitative research, therefore, we cannot ignore the importance of coding them. Coding refers to the process through which we fragment or segment the data according to the objectives and research questions that we have proposed (Strauss \& Corbin, 2002). The method used to classify the data has been content analysis (Bardin, 1986). Once the information was collected, it was distributed according to the units of meaning that were emerging. These units of meaning were labelled by codes that, finally, were grouped into thematic categories, following the recommendations of L'Écuyer (1990), who points out that they are grouped into categories or broader topics under a generic title that brings together all the sentences whose meaning is related (Figure 2). As we can see in this figure the key component of our study is "Learning Resources" which is related to resources that teachers use because they allow them to satisfy a need or achieve what they want. Later, data was divided into two main components: technological resources and personal resources.

On the one hand, personal resources include people and groups of people that have influenced or influence the configuration of the learning ecology of each of the teachers This category was named "The Importance of personal resources". On the other hand, the component of technological resources include resources related to ICT that help each teacher to develop professionally and configure their learning ecology. In this category, we can find three subcategories named:

\section{"How they learned to use technological resources", \\ "What and how they use the technological resources", and}


"How they value the technological resources".

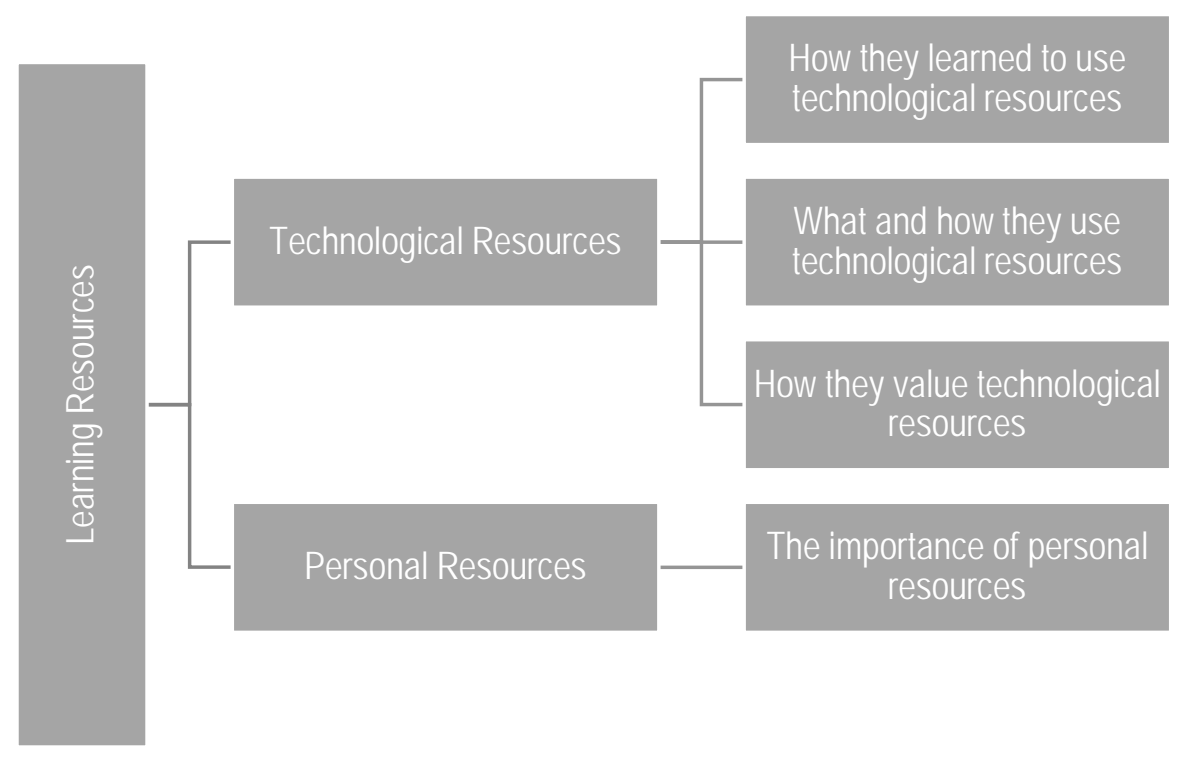

Figure 2. Analysis categories

\section{Results}

At this point we are going to present the results of the study organized in the following four categories:

\section{How they learned to use technological resources}

The responses of the five participants allow us to differentiate two groups to explain how they learned to use technological resources. On the one hand, there is a first group in which there are two teachers (Eduardo and Yelina) who have been learning to use technology, at first, through courses and, later on, in a more self-taught way:

"If there is something that I do not know, I look for tutorials or do courses related to that (...)" (E2-C, 15).

It is important to point out that Eduardo is passionate and very interested in the ICT world, so he is very involved in updating himself in this area. In addition, he did his thesis on the computerization of schools and that helped him a lot to advance in this subject. On the other hand, there is a second group formed by three teachers (Ana, Belén and Rebeca), who have been discovering the potentialities of ICT through their peers:

"Mainly through other colleagues who use ICT to train and through the social networks that allow you to know different groups of teachers or educational websites that advertise or promote learning using technology" (E2-E, 15). 


\section{What and how they use technological resources}

All of them, to a greater or lesser extent, use digital tools to facilitate the development of their classes. The difference resides in the possibilities offered by the schools in which they teach and the ability that each one has to manage with these tools with a certain skill.

Thus, both Yelina and Eduardo use collaborative work tools (Dropbox, Google Drive...), applications to communicate with family and other professionals (WhatsApp, Telegram...), applications to work on aspects such as reading and writing, vocabulary, story creation, or applications for the management of blogs and educational web pages. In addition, Yelina uses other types of technological resources:

"I also use different videos, documentaries and/or presentations to complement the teaching-learning process. For example, if we are talking about animals and reproduction, I use videos with the reproduction of different types of animals (viviparous and oviparous)" (E2-E, 15).

In the same way, Eduardo uses Edmodo to work together with his students. In addition, he has several educational blogs, creates activities and develops educational material.

On the other hand, Ana, Belén and Rebeca do not have such a wide knowledge and they limit themselves to using resources such as the Smartphone, the Interactive Digital Whiteboard, the computer and instant messaging applications such as WhatsApp. Only Belén explains that blogs are a resource that is especially useful:

"The world of blogs is very interesting because you can find people who have a lot of information" (E2-B, 12).

\section{How they value technological resources}

As we can see in the results, both Eduardo and Yelina are two teachers very committed to new technologies, so they value them in a very positive way. Yelina says that the flexibilization of schools to adapt to the needs of today's society involves the exploitation of ICT in teaching processes. According to her, this would imply changes in the conception of the students, changes in the teachers and administrative changes in relation to the design and distribution of the teaching and with the communication systems that the institution establishes:

\footnotetext{
"ICT, nowadays, are fundamental in the teaching-learning process. On the one hand, we teach children who learn to use a Smartphone before they speak, so the teaching must be adapted to this change. On the other hand, new technologies facilitate visual and participatory teaching, in which students learn by doing, and I consider it fundamental" (E2-E, 12).
} 
Eduardo is passionate about new technologies. He says:

"I really like this world, to be constantly learning as platforms or digital educational resources are advancing because it is a way to update yourself. I have always done many courses on ICT and I have also given them, since I believe it is important and essential that teachers have, at least, a basic command in their use and in their educational use" (E2-C, 11).

Despite the fact that Rebeca has more limited knowledge of ICT, she considers that these are fundamental in daily life in the classroom, because they allow her to develop new knowledge strategies and new methodologies based on the discovery and research:

"They help me to present knowledge and promote greater autonomy in students, developing in them the ability to learn" (E2-D, 12).

Finally, Ana and Belén highlight both positive and negative aspects of ICT. On the one hand, Ana explains that the benefits of using these types of tools are many, among which she highlights the following:

"Create material, search for information, as an evaluation method (recordings of exhibitions), etc." (E2 -A, 8).

On the other hand, their opinion about virtual networks and platforms is not so positive:

"I value them not great because I think they eliminate a lot of direct connection from person to person, which I consider essential within the educational sphere" (E2-A,11).

Finally, Belén tells us that ICTs have completely changed the way she teaches classes:

"I was aware in my career that a change was necessary for the classroom, and I think that in some way ICTs offer us this " $(E 2-B, 14)$.

However, she believes that they also have negative aspects:

"The students, in general, have a serious attention problem. And I think it's related to ICT, because, in addition to the computer, the child has a PlayStation, an Xbox, a Game Boy ... and more games on the computer. In the computer, it is very easy to go from one information to another without going deep. Without having to pay attention to what you are reading until you find what you want. It's very easy, and then you start reading and you say this is not useful, but maybe what you were looking for was in the middle of that" $(E 2-B, 11)$. 


\section{The importance of personal resources}

Finally, it is convenient to point out that, in addition to the technological resources, all the participants emphasize the importance of the people in their training, from their family or friends to their colleagues. Eduardo, one of the teachers most committed to the use of ICT, says:

"I am still in contact with colleagues from the university and colleagues from other schools where I was working. Through social networks, we are always in contact, commenting on doubts or opinions on various topics. We also make casual encounters in which you talk about everything a little "(E2-C, 6).

In the same way, Ana affirms:

"People have always occupied a large place in my continuing education, perhaps I can say that it is the most important aspect because from them you learn unwittingly and totally unconsciously" (E2-A, 12).

\section{Conclusions}

As we have seen throughout this research, one of the most important topics in the configuration of learning ecologies derives from the use of ICT (Sangrà, González Sanmamed, \& Guitert, 2013, González-Sanmamed, Sangrá, Souto-Seijo, \& Estévez, 2018). The continuous and fast succession of changes has gone beyond the traditional response of teachers' professional training based on courses with a specific beginning and end. Currently, there are multiple resources that can help teachers to develop professionally and stay updated and, therefore, it is so important to know what is the learning of ICT of teachers, what and how they use these resources, how they value them and what others resources they consider fundamental in their training.

In this research, it has been observed that some of the participants learned to use technological resources in a self-taught way and others have introduced into this world with the help of their workmates. It should be noted that all of them use, to a greater or lesser extent, digital tools to facilitate the development of their classes. The difference resides in the possibilities offered by the schools in which they teach and the ability that each one has to manage with these tools with a certain skill. In addition, the five participants found positive the use of ICT, both to teach and to learn, but also reveal some negative aspects, such as the loss of personal treatment with people. Finally, in addition to technological resources, all participants highlight the importance of personal interactions in their training.

Finally, we would like to point out that our study is of an exploratory type and, for this reason, we thought it would be appropriate to expand our research using other types of data collection techniques, such as document analysis or observation. In addition, it could be very interesting to complement this qualitative study, with a quantitative one, to investigate more in depth and from different methodological perspectives the learning ecologies of Primary 
Education teachers. This would allow us to better understand what resources teachers have in an increasingly uncertain social context.

\section{References}

Bardin, L. (1986). L'analyse de contenu. Paris: PUF.

Barron, B. (2006). Interest and Self-Sustained Learning as Catalysts of Development: A Learning Ecology Perspective. Human Development, 49(4), 193-224.

Carril, P. C. M., Sanmamed, M. G., \& Sellés, N. H. (2013). Pedagogical roles and competencies of university teachers practicing in the e-learning environment. The International Review of Research in Open and Distributed Learning, 14(3), 462-487.

Clandinin, D. J., \& Connelly, F. M. (2000). Narrative inquiry: Experience and story in qualitative research.

Corbin, J., \& Strauss, A. (2014). Basics of qualitative research: Techniques and procedures for developing grounded theory. London: Sage.

Creswell, J. W. (2013). Research design: Qualitative, quantitative, and mixed methods approaches. Thousand Oaks: Sage.

Eraut, M. (2009). How Professionals Learn through Work. In N. J. Jackson (Ed.), Learning to be Professional through a Higher Education (Chapter 2). Authorhouse: E-book. Retrieved from http://learningtobeprofessional.pbworks.com/How-professionals-learn-throughwork

Glaser, B. G., \& Strauss, A. L. (1967). The discovery of grounded theory: strategies for qualitative theory. New Brunswick: Aldine Transaction.

Glaser, B. G., \& Strauss, A. L. (1999). Discovery of Grounded Theory. New York: Routledge. https://doi.org/10.4324/9780203793206

González-Sanmamed, M., Sangrà, A., Souto-Seijo, A., \& Estévez, I. (2018). Ecologías de aprendizaje en la Era Digital: desafíos para la Educación Superior. Publicaciones, 48, 11-38. http://doi.org/10.30827/publicaciones.v48i1.7329

Imbernón, F. (2014). Calidad de enseñanza y formación del profesorado: un cambio necesario. Barcelona: Octaedro.

L'Écuyer, R. (1990). Méthodologie de l'analyse développementale de contenu. Sillery. Presses de l'Université du Québec, 51-120.

Sangrà, A., \& González-Sanmamed, M. (2011). The role of information and communication technologies in improving teaching and learning processes in primary and secondary schools. Australasian Journal of Educational Technology, 26(8).

Sangrà, A., Gonzalez-Sanmamed, M., \& Guitert, M. (2013). Learning ecologies: Informal professional development opportunities for teachers. Proceedings of the Educational Media (ICEM), 2013 IEEE 63 ${ }^{\text {rd }}$ Annual Conference International Council for. IEEE, 1-2. 
Siemens, G. (2010). Conectivismo: Una teoría de aprendizaje para la era digital. Conectados en el ciberespacio, 20, 77-140.

Strauss, A., \& Corbin, J. (2002). Bases de la investigación cualitativa: técnicas y procedimientos para desarrollar la teoría fundamentada. Medellín: Editorial de Antioquia.

\section{Acknowledgments}

This study has been conducted in the framework of the research project (ECO4LEARN-HE), funded by the Ministry of Economy and Finance (Reference EDU2015-67907-R), and thanks to the funding received by one of the authors, Iris Estévez, in the FPI programme from the Ministry of Economy and Finance (BES-2016-077330). 